\title{
Study of the $\left[\mathrm{Zn}\left(\mathrm{H}_{2} \mathrm{O}\right)_{4} \mathrm{CuEDTA}\right] \cdot 2 \mathrm{H}_{2} \mathrm{O}$ Complex, a Potential \\ Trace-metal Supplier: Synthesis, Crystal Structure, Spectroscopic Behavior and Metal Release
}

\author{
Eduardo Santi $^{\mathrm{a}}$, Enrique J. Baran ${ }^{\mathrm{b}}$, Javier Ellena ${ }^{\mathrm{c}}$, Otaciro R. Nascimento ${ }^{\mathrm{d}}$, \\ and María H. Torre ${ }^{\mathrm{a}}$ \\ ${ }^{a}$ Química Inorgánica, DEC, Facultad de Química, Universidad de la República, Gral. Flores 2124, \\ Montevideo, Uruguay

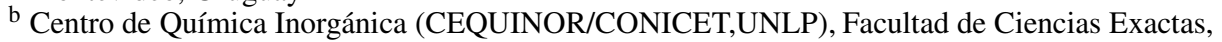 \\ Universidad Nacional de La Plata, 1900-La Plata, Argentina \\ ${ }^{c}$ Laboratorio de Cristalografía, Instituto de Física de São Carlos, USP, C.P. 369, 13560, São Carlos \\ (SP), Brazil \\ ${ }^{d}$ Grupo de Biofísica Sérgio Mascarenhas, Instituto de Física de São Carlos, USP, C.P. 369, 13560, \\ São Carlos (SP), Brazil
}

Reprint requests to Prof. M. H. Torre. E-mail: mtorre@fq.edu.uy

Z. Naturforsch. 2008, 63b, 1361 - 1366; received September 20, 2008

\begin{abstract}
Ethylenediaminetetraacetic acid $\left(\mathrm{H}_{4}\right.$ EDTA) is widely used in the pharmaceutical and bromatological industries and as a drug in chelation therapies. Besides, coordinated with metal ions it is used for the supplementation of essential trace elements. In this work the synthesis, crystallographic, and spectroscopic studies (EPR, IR, UV/Vis) of $\left[\mathrm{Zn}\left(\mathrm{H}_{2} \mathrm{O}\right)_{4} \mathrm{CuEDTA}\right] \cdot 2 \mathrm{H}_{2} \mathrm{O}$ are reported. The release of the metal cations at gastric $\mathrm{pH}$ was also investigated.
\end{abstract}

Key words: Copper and Zinc Complexes, EDTA, X-Ray Diffraction, Spectroscopy, Metal Release

\section{Introduction}

Ethylenediaminetetraacetic acid $\left(\mathrm{H}_{4}\right.$ EDTA) is a diaminotetracarboxylic acid often used in pharmaceutical and bromatological formulations, whose action has been correlated with its ability to chelate divalent metal cations, interacting with one or with various different cations [1].

In the pharmaceutical industry it is used to complex and to inactivate trace metals that may catalyze oxidative degradation of drugs. Besides, it often acts as a potentiator of the antimicrobial effect of preservation agents (especially against gram-negative bacteria), disrupting the permeability of the outer membrane by removal of divalent cation bridging to the peptidoglycan cell wall $[2,3]$.

In the bromatological area there are different sources of metal contamination including raw material impurities like solvents, containers, and equipment employed in the manufacturing processes that can affect the color, rancidity and texture of food. For these reasons it is usual to use EDTA ${ }^{4-}$ (usually as its tetrasodium salt) to prevent changes in food like discol- oration of potatoes, fishes and mollusca, and to stabilize vitamins [3].

By these two ways EDTA $^{4-}$ can enter the body through foods or pharmaceuticals and it can interact with some of the essential metal cations.

In addition, EDTA ${ }^{4-}$ is used as a drug in chelation therapies, with the aim to remove toxic metals or essential metals in excess [3-5]. Moreover, metal complexes of EDTA ${ }^{4-}$ are used for the supplementation of essential trace elements. For instance, $\mathrm{Na}_{2} \mathrm{CuEDTA}$ and $\mathrm{CaCuEDTA}$ injections are used in veterinary pharmacology for the supplementation of $\mathrm{Cu}$ or $\mathrm{Cu} / \mathrm{Ca}$ in cows and sheep that shepherd in regions with low copper levels [6,7], whereas NaFeEDTA has been recommended as an iron fortificant agent [8].

Taking into account these antecedents, the study of these systems is considered as relevant from both, the bioinorganic and the pharmacological points of view. The synthesis and structural characterization of almost all the simple EDTA ${ }^{4-}$ complexes with the essential first row transition metals has been reported. On the contrary, the study of EDTA ${ }^{4-}$ complexes containing different coordinated metal cations has not been so 
plentiful yet. As an example, structural information about EDTA ${ }^{4-}$ complexes like $\left[\mathrm{Ag}\left(\mathrm{H}_{2} \mathrm{O}\right)_{2}\right.$ FeEDTA] $\mathrm{H}_{2} \mathrm{O}$ [9] [Mn $\left.\left(\mathrm{H}_{2} \mathrm{O}\right)_{4} \mathrm{CuEDTA}\right] \cdot 2 \mathrm{H}_{2} \mathrm{O}$ [10], [Cu(en $)_{2}-$ $\left.\left(\mathrm{H}_{2} \mathrm{O}\right) \mathrm{NiEDTA}\right] \cdot 3 \mathrm{H}_{2} \mathrm{O}$ [11] , and [ $\left.\mathrm{Sr}\left(\mathrm{H}_{2} \mathrm{O}\right)_{3} \mathrm{CuEDTA}\right]$ $\cdot \mathrm{H}_{2} \mathrm{O}$ [12] was reported. For the $\mathrm{Cu}(\mathrm{II}) / \mathrm{Zn}$ (II)-EDTA complex, unit cell dimensions and space group were initially determined by $\mathrm{X}$-ray powder diffractometry [13], and the structure of [ $\left.\mathrm{Zn}\left(\mathrm{H}_{2} \mathrm{O}\right)_{4} \mathrm{CuEDTA}\right] \cdot 2 \mathrm{H}_{2} \mathrm{O}$ was determined by Leont'eva et al. some years later by single crystal methods [14].

As a part of our current work on metal complexes with recognized pharmacological activity $[6,7$, 15 - 17] we are preparing EDTA $^{4-}$ complexes containing simultaneously two different cations [7] with the aim to study their suitability for the supplementation of essential metals.

In this work the crystal structure of $\left[\mathrm{Zn}\left(\mathrm{H}_{2} \mathrm{O}\right)_{4}\right.$ CuEDTA] $\cdot 2 \mathrm{H}_{2} \mathrm{O}$ was re-examined and refined to higher precision than in the previous study [14]. Besides, the spectroscopic behavior (EPR, IR and $\mathrm{UV} / \mathrm{Vis}$ ) as well as the release of $\mathrm{Zn}$ (II) and $\mathrm{Cu}$ (II) ions at gastric $\mathrm{pH}$ were investigated and compared with the results for the simple $\left[\mathrm{CuH}_{2}\right.$ EDTA] $\cdot \mathrm{H}_{2} \mathrm{O}$ complex.

\section{Results and Discussion}

\section{Crystal structure}

The crystal structure of $\left[\mathrm{Zn}\left(\mathrm{H}_{2} \mathrm{O}\right)_{4} \mathrm{CuEDTA}\right]$. $2 \mathrm{H}_{2} \mathrm{O}$ was redetermined with a higher precision than that previously reported. In this work the final $R 1$ value is 0.040 while that found in reference [11] was 0.073 . An ORTEP [18] drawing of the structure is presented in

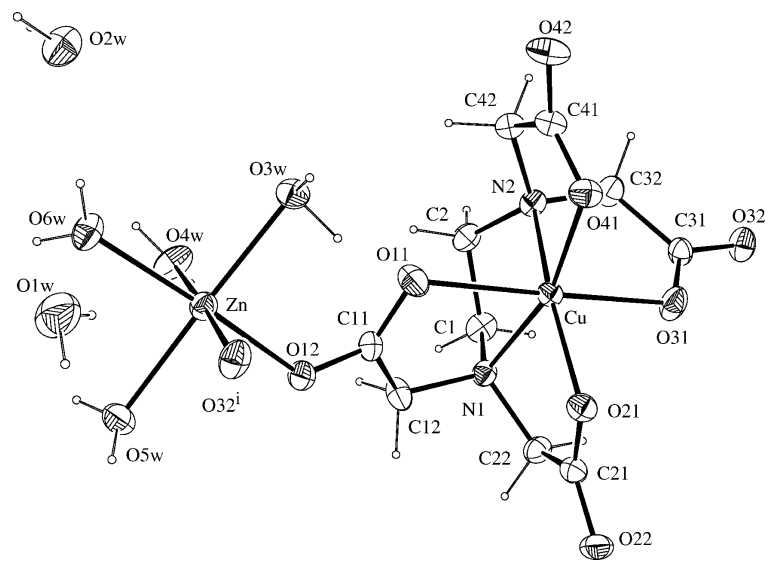

Fig. 1. ORTEP-III view of the asymmetric unit of the complex [ $\left.\mathrm{Zn}\left(\mathrm{H}_{2} \mathrm{O}\right)_{4} \mathrm{CuEDTA}\right] \cdot 2 \mathrm{H}_{2} \mathrm{O}$, showing the atom labelling and the $50 \%$ probability ellipsoids. Symmetry transformation used to generate equivalent atoms: ${ }^{\mathrm{i}} x-1 / 2,-y+3 / 2$, $z$.
Table 1. Selected bond lengths $(\AA)$ and angles (deg) around the $\mathrm{Zn}(\mathrm{II})$ and $\mathrm{Cu}(\mathrm{II})$ ions in $\left[\mathrm{Zn}\left(\mathrm{H}_{2} \mathrm{O}\right)_{4} \mathrm{CuEDTA}\right] \cdot 2 \mathrm{H}_{2} \mathrm{O}$.

\begin{tabular}{lrlr}
\hline $\mathrm{Cu}-\mathrm{O}(41)$ & $1.979(3)$ & $\mathrm{Zn}-\mathrm{O}(32)^{\mathrm{i}}$ & $2.080(2)$ \\
$\mathrm{Cu}-\mathrm{O}(21)$ & $2.019(2)$ & $\mathrm{Zn}-\mathrm{O}(6 \mathrm{~W})$ & $2.087(3)$ \\
$\mathrm{Cu}-\mathrm{N}(1)$ & $2.042(3)$ & $\mathrm{Zn}-\mathrm{O}(12)$ & $2.095(2)$ \\
$\mathrm{Cu}-\mathrm{N}(2)$ & $2.050(3)$ & $\mathrm{Zn}-\mathrm{O}(5 \mathrm{~W})$ & $2.095(3)$ \\
$\mathrm{Cu}-\mathrm{O}(31)$ & $2.208(2)$ & $\mathrm{Zn}-\mathrm{O}(4 W)$ & $2.119(3)$ \\
$\mathrm{Cu}-\mathrm{O}(11)$ & $2.288(2)$ & $\mathrm{Zn}-\mathrm{O}(3 \mathrm{~W})$ & $2.120(3)$ \\
$\mathrm{O}(41)-\mathrm{Cu}-\mathrm{O}(21)$ & $108.71(11)$ & $\mathrm{O}(12)-\mathrm{Zn}-\mathrm{O}(5 \mathrm{~W})$ & $87.91(11)$ \\
$\mathrm{O}(41)-\mathrm{Cu}-\mathrm{N}(1)$ & $163.63(12)$ & $\mathrm{O}(6 \mathrm{~W})-\mathrm{Zn}-\mathrm{O}(4 \mathrm{~W})$ & $87.56(11)$ \\
$\mathrm{O}(21)-\mathrm{Cu}-\mathrm{N}(1)$ & $82.47(11)$ & $\mathrm{O}(12)-\mathrm{Zn}-\mathrm{O}(4 \mathrm{~W})$ & $81.63(11)$ \\
$\mathrm{O}(41)-\mathrm{Cu}-\mathrm{N}(2)$ & $83.43(12)$ & $\mathrm{O}(5 \mathrm{~W})-\mathrm{Zn}-\mathrm{O}(4 \mathrm{~W})$ & $90.93(12)$ \\
$\mathrm{O}(21)-\mathrm{Cu}-\mathrm{N}(2)$ & $163.84(11)$ & $\mathrm{O}(6 \mathrm{~W})-\mathrm{Zn}-\mathrm{O}(3 \mathrm{~W})$ & $92.69(11)$ \\
$\mathrm{N}(1)-\mathrm{Cu}-\mathrm{N}(2)$ & $88.14(12)$ & $\mathrm{O}(12)-\mathrm{Zn}-\mathrm{O}(3 \mathrm{~W})$ & $91.72(10)$ \\
$\mathrm{O}(6 \mathrm{~W})-\mathrm{Zn}-\mathrm{O}(12)$ & $168.43(11)$ & $\mathrm{O}(5 \mathrm{~W})-\mathrm{Zn}-\mathrm{O}(3 \mathrm{~W})$ & $177.35(10)$ \\
$\mathrm{O}(6 \mathrm{~W})-\mathrm{Zn}-\mathrm{O}(5 \mathrm{~W})$ & $88.16(12)$ & $\mathrm{O}(4 \mathrm{~W})-\mathrm{Zn}-\mathrm{O}(3 \mathrm{~W})$ & $91.61(11)$ \\
\hline $\mathrm{S}$ & &
\end{tabular}

Symmetry transformations used to generate equivalent atoms: ${ }^{i} x-$ $1 / 2,-y+3 / 2, z$.

Fig. 1. Selected bond lengths and angles around both metals are presented in Table 1 . The $\mathrm{Zn}$ (II) ion is in a slightly distorted octahedral environment, and its coordination sphere is constituted of six $\mathrm{O}$ atoms from four water molecules and two carboxylic groups of the EDTA $^{4-}$ ligand which acts as a bridge between the metal atoms. The $\mathrm{Cu}(\mathrm{II})$ cation lies in a tetragonally distorted octahedron, coordinated through two $\mathrm{O}$ atoms and two $\mathrm{N}$ atoms from one EDTA ${ }^{4-}$ dianion, acting as a polydentate ligand, and two $\mathrm{O}$ atoms of bridging EDTA $^{4-}$ dianions.

The axial positions on $\mathrm{Cu}(\mathrm{II})$ are occupied by two carboxylate oxygen atoms $\left(d_{\mathrm{Cu}-\mathrm{O}}=2.288(2)\right.$ and $2.208(2) \AA$ ), while the equatorial plane is formed by two amine nitrogen atoms and the other two carboxylate oxygen atoms. This copper environment is thus slightly different to that reported for the $\left[\mathrm{CuH}_{2}\right.$ EDTA] $\cdot \mathrm{H}_{2} \mathrm{O}$ complex [19] where the axial positions are occupied by one nitrogen atom $\left(d_{\mathrm{Cu}-\mathrm{N}}=\right.$ $2.291 \AA)$ and one oxygen atom $\left(d_{\mathrm{Cu}-\mathrm{O}}=2.467\right)$ while the equatorial plane is formed by three $\mathrm{O}$ and one $\mathrm{N}$ coordinating atoms.

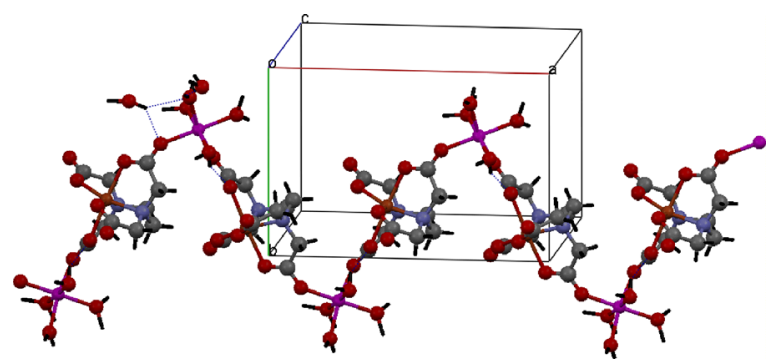

Fig. 2. Packing of the complex $\left[\mathrm{Zn}\left(\mathrm{H}_{2} \mathrm{O}\right)_{4} \mathrm{CuEDTA}\right] \cdot 2 \mathrm{H}_{2} \mathrm{O}$, showing the polymeric chain along the crystallographic $a$ axis. 
Table 2. Intra- and intermolecular hydrogen bond parameters (A, deg).

\begin{tabular}{|c|c|c|c|c|}
\hline $\mathrm{D}-\mathrm{H} \cdots \mathrm{A}$ & $\mathrm{D}-\mathrm{H}$ & $\mathrm{D} \cdots \mathrm{A}$ & $\mathrm{H} \cdots \mathrm{A}$ & $\overline{\mathrm{D}-\mathrm{H} \cdots \mathrm{A}}$ \\
\hline \multicolumn{5}{|c|}{ Intramolecular interactions } \\
\hline $\mathrm{O} 3 \mathrm{~W}-\mathrm{H} 32 \mathrm{~W} \cdots \mathrm{O} 11$ & 0.952 & $2.677(4)$ & $1.820(3)$ & $148.2(2)$ \\
\hline $\mathrm{O} 6 \mathrm{~W}-\mathrm{H} 62 \mathrm{~W} \cdots \mathrm{O} 2 \mathrm{w}$ & 0.850 & $2.683(4)$ & $1.983(3)$ & $139.1(2)$ \\
\hline \multicolumn{5}{|c|}{ Intermolecular interactions } \\
\hline $\mathrm{N} 224-\mathrm{H} 22 \mathrm{C} \cdots \mathrm{O} 123^{\mathrm{i}}$ & 0.880 & $3.011(8)$ & $2.146(5)$ & $167.7(4)$ \\
\hline $\mathrm{O} 4 \mathrm{~W}-\mathrm{H} 42 \mathrm{~W} \cdots \mathrm{O} 42^{\mathrm{i}}$ & 0.843 & $2.743(4)$ & $1.911(3)$ & $168.5(2)$ \\
\hline $\mathrm{O} 1 \mathrm{~W}-\mathrm{H} 11 \mathrm{~W} \cdots \mathrm{O} 32^{\mathrm{ii}}$ & 0.830 & $2.960(4)$ & $2.258(2)$ & $142.6(3)$ \\
\hline $\mathrm{O} 2 \mathrm{~W}-\mathrm{H} 22 \mathrm{~W} \cdots \mathrm{O} 12^{\mathrm{iii}}$ & 0.965 & $2.786(4)$ & $2.015(3)$ & $135.4(2)$ \\
\hline $\mathrm{O} 3 \mathrm{~W}-\mathrm{H} 31 \mathrm{~W} \cdots \mathrm{O} 22^{\mathrm{iii}}$ & 0.869 & $2.799(4)$ & $1.943(3)$ & $168.4(2)$ \\
\hline $\mathrm{O} 5 \mathrm{~W}-\mathrm{H} 51 \mathrm{~W} \cdots \mathrm{O} 22^{\mathrm{iv}}$ & 0.819 & $2.744(4)$ & $1.942(3)$ & $166.2(2)$ \\
\hline $\mathrm{O} 4 \mathrm{~W}-\mathrm{H} 41 \mathrm{~W} \cdots \mathrm{O} 31^{\mathrm{iv}}$ & 0.816 & $2.682(4)$ & $1.910(2)$ & $157.4(2)$ \\
\hline $\mathrm{O} 6 \mathrm{~W}-\mathrm{H} 61 \mathrm{~W} \cdots \mathrm{O} 21^{\mathrm{iv}}$ & 0.850 & $2.893(4)$ & $2.092(3)$ & $156.9(2)$ \\
\hline $\mathrm{O} 2 \mathrm{~W}-\mathrm{H} 21 \mathrm{~W} \cdots \mathrm{O} 41^{\mathrm{iv}}$ & 0.835 & $2.777(4)$ & $1.975(3)$ & $160.7(2)$ \\
\hline $\mathrm{O} 5 \mathrm{~W}-\mathrm{H} 52 \mathrm{~W} \cdots \mathrm{O} 42^{\mathrm{v}}$ & 0.828 & $2.824(4)$ & $2.015(3)$ & $165.5(2)$ \\
\hline
\end{tabular}

Two hydrate water molecules complete the structure and form hydrogen bonds with the water molecules coordinated to the $\mathrm{Zn}$ (II) cation.

The crystal thus features polymeric zig-zag chains along the crystallographic $a$ axis and is stabilized by intra- and intermolecular hydrogen bonds, as depicted in Fig. 2. Details on the hydrogen bonding parameters are shown in Table 2.

\section{Spectroscopic measurements}

The electronic spectrum of $\left[\mathrm{Zn}\left(\mathrm{H}_{2} \mathrm{O}\right)_{4} \mathrm{CuEDTA}\right]$. $2 \mathrm{H}_{2} \mathrm{O}$ recorded in a Nujol mull showed a wide asymmetric $d-d$ band centered at $712 \mathrm{~nm}$ and a shoulder at $761 \mathrm{~nm}$ in agreement with the presence of a tetragonally distorted octahedral coordination sphere of the $\mathrm{Cu}$ atom [20]. The aqueous solution spectrum showed a wide $d-d$ band centered at $730 \mathrm{~nm}$. The bands obtained for $\left[\mathrm{CuH}_{2}\right.$ EDTA $] \cdot \mathrm{H}_{2} \mathrm{O}$ in Nujol were at 712 and $765 \mathrm{~nm}$, while the aqueous solution showed a wide band at $742 \mathrm{~nm}$. The comparison between both spectra indicated that the presence of the $\mathrm{Zn}$ (II) ion only slightly affects the copper environment in the crystaline state.

The IR spectrum of $\left[\mathrm{Zn}\left(\mathrm{H}_{2} \mathrm{O}\right)_{4} \mathrm{CuEDTA}\right] \cdot 2 \mathrm{H}_{2} \mathrm{O}$ showed several characteristic bands $\left(\mathrm{cm}^{-1}\right)$ at 3394 $[\mathrm{s}, v(\mathrm{OH})], 1591\left[\mathrm{~s}, v_{\mathrm{as}}\left(\mathrm{COO}^{-}\right)\right], 1405$ and $1382[\mathrm{~s}$, bridge and monodentate $\left.v_{\mathrm{s}}\left(\mathrm{COO}^{-}\right)\right]$, among others, as previously reported [7].

The EPR spectra of $\left[\mathrm{Zn}\left(\mathrm{H}_{2} \mathrm{O}\right)_{4} \mathrm{CuEDTA}\right] \cdot 2 \mathrm{H}_{2} \mathrm{O}$ and $\left[\mathrm{CuH}_{2}\right.$ EDTA $] \cdot \mathrm{H}_{2} \mathrm{O}$ are shown in Fig. 3. The EPR spectrum for [ $\mathrm{CuH}_{2}$ EDTA] $\cdot \mathrm{H}_{2} \mathrm{O}$ presents clearly the three $g$ values as described by Hathaway et al. [21],
Table 3. Copper and zinc concentration $\left(\mu \mathrm{g} \mathrm{mL}^{-1}\right)$ in water and $0.1 \mathrm{M} \mathrm{HCl}$ solutions determined by atomic absorption spectroscopy in the ion exchange experiments with [Zn$\left.\left(\mathrm{H}_{2} \mathrm{O}\right)_{4} \mathrm{CuEDTA}\right] \cdot 2 \mathrm{H}_{2} \mathrm{O}^{\mathrm{a}}$.

\begin{tabular}{lllllll}
\hline & \multicolumn{3}{c}{ Water } & \multicolumn{3}{c}{$\mathrm{HCl} \mathrm{0.1} \mathrm{M}$} \\
& A Cu/Zn & B Cu/Zn & C Cu/Zn & D Cu/Zn & E Cu/Zn & F Cu/Zn \\
\hline Resin A & $169 / 177$ & $0 / 0$ & $160 / 179$ & $171 / 177$ & $0 / 0$ & $178 / 176$ \\
Resin B & $166 / 177$ & $149 / 54$ & $19 / 130$ & $165 / 177$ & $149 / 78$ & $19 / 99$ \\
\hline
\end{tabular}

${ }^{\mathrm{a}} \mathbf{A}$ and $\mathbf{D}$ : copper and zinc concentration $\left(\mu \mathrm{g} \mathrm{mL}{ }^{-1}\right)$ of the initial solution of the complex prepared in water and $0.1 \mathrm{M} \mathrm{HCl}$, respectively; $\mathbf{B}$ and $\mathbf{E}$ : copper and zinc concentration $\left(\mu \mathrm{g} \mathrm{mL}^{-1}\right)$ of the eluate with water; $\mathbf{C}$ and $\mathbf{F}$ : copper and zinc concentration $\left(\mu \mathrm{g} \mathrm{mL}^{-1}\right)$ of the eluate after resin regeneration.

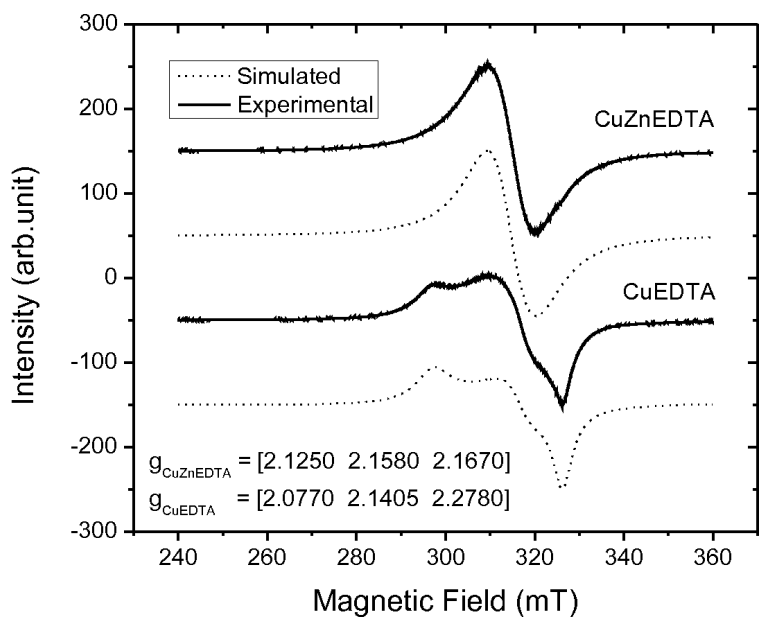

Fig. 3. X-Band EPR spectra of powdered $\left[\mathrm{Zn}\left(\mathrm{H}_{2} \mathrm{O}\right)_{4}\right.$ CuEDTA] $\cdot 2 \mathrm{H}_{2} \mathrm{O}$ and $\left[\mathrm{CuH}_{2}\right.$ EDTA] $\cdot \mathrm{H}_{2} \mathrm{O}$ (solid lines), measured at $4.3 \mathrm{~K}$, and their respective simulations (dotted lines) using EASYSPIN programs [22].

whereas the spectrum of $\left[\mathrm{Zn}\left(\mathrm{H}_{2} \mathrm{O}\right)_{4} \mathrm{CuEDTA}\right] \cdot 2 \mathrm{H}_{2} \mathrm{O}$ presents only one asymmetric and broad line. The simulation of the spectrum [22] gave the following $g$ values: $g_{1}=2.1250, g_{2}=2.1580$ and $g_{3}=2.1670$, where the anisotropy is largely averaged by exchange interactions promoted by hydrogen bonds between neighboring molecules as shown by the crystallographic packing (see Fig. 2).

\section{Ion exchange experiments}

Table 3 contains the atomic absorption data for the quantification of copper and zinc in the ion exchange experiments with [ $\left.\mathrm{Zn}\left(\mathrm{H}_{2} \mathrm{O}\right)_{4} \mathrm{CuEDTA}\right] \cdot 2 \mathrm{H}_{2} \mathrm{O}$. Both $\mathrm{Zn}$ (II) and $\mathrm{Cu}$ (II) were retained by the sulfonic group of the strong resin $\mathrm{A}$, either for $0.1 \mathrm{M} \mathrm{HCl}$ or water. This result shows that the complexes between $\mathrm{Zn}$ (II) and $\mathrm{Cu}(\mathrm{II})$ with the sulfonic groups of resin $\mathrm{A}$ have a stability constant higher than the Cu-EDTA constant under the experimental conditions. In the case of 
resin $\mathrm{B}$, the $\mathrm{Zn}$ (II) was partially released by the complex and was retained in both water and $0.1 \mathrm{M} \mathrm{HCl}$ by the acetate group. On the opposite, copper possibly remains in chelated form as the $[\mathrm{Cu}(\text { EDTA })]^{2-}$ complex, and is eluted.

In the case of $\left[\mathrm{CuH}_{2} \mathrm{EDTA}\right] \cdot \mathrm{H}_{2} \mathrm{O}$, the copper concentration in the initial $0.1 \mathrm{M} \mathrm{HCl}$ solution was $142 \mu \mathrm{g} \mathrm{mL}^{-1}$, while in the eluate with water it was almost 0 and after the regeneration with $1 \mathrm{M} \mathrm{HCl}$ all the copper was eluted.

To conclude, partial release of $\mathrm{Zn}$ (II) is observed at gastric $\mathrm{pH}$ and with both resins, whose functional groups might represent potential ligands in the gastric tract. On the contrary, copper is released under the experimental conditions only in the presence of a strong ligand that competes with EDTA $^{4-}$.

\section{Conclusions}

Besides a redetermination of the crystal structure of $\left[\mathrm{Zn}\left(\mathrm{H}_{2} \mathrm{O}\right)_{4} \mathrm{CuEDTA}\right] \cdot 2 \mathrm{H}_{2} \mathrm{O}$, the spectroscopic behavior (EPR, IR and UV/Vis) was analyzed showing that the $\mathrm{Zn}(\mathrm{II})$ ion does not affect significantly the coordination environment of the $\mathrm{Cu}$ (II) ion in the solid state.

Taking into account the ion exchange experiments, the release of the two metals depends not only on the $\mathrm{pH}$ but also on the ligands present in the media.

\section{Experimental Section}

\section{Synthesis of the complexes}

All starting materials were commercially available analytical-grade chemicals and were used without further purification. Both complexes were synthesized according to the procedures described by Pfeiffer and Schmitz [23]. The elemental analyses were performed with a Carlo Erba EA1108 elemental analyzer, whereas the copper and zinc contents were determined by atomic absorption spectroscopy.

For the preparation of $\left[\mathrm{CuH}_{2} \mathrm{EDTA}\right] \cdot \mathrm{H}_{2} \mathrm{O}$ a suspension of $1.10 \mathrm{~g}$ of $\mathrm{CuCO}_{3} \cdot \mathrm{Cu}(\mathrm{OH})_{2}$ and $2.92 \mathrm{~g}$ of $\mathrm{H}_{4}$ EDTA in $200 \mathrm{~mL}$ of distilled water was heated at $50{ }^{\circ} \mathrm{C}$ during half an hour with continuous stirring. The unreacted material was separated by filtration, and the blue solution was concentrated over a water bath to 50-60 mL. After cooling, the crystalline mass obtained was filtered off, washed several times with cold methanol and finally dried in air at r.t. Yield: $36 \%(1.0 \mathrm{~g})$. Analysis for $\left[\mathrm{CuH}_{2} \mathrm{EDTA}\right] \cdot \mathrm{H}_{2} \mathrm{O}\left(\mathrm{C}_{10} \mathrm{H}_{16} \mathrm{~N}_{2}-\right.$ $\mathrm{O}_{9} \mathrm{Cu}$ ): calcd. $\mathrm{C} 32.31, \mathrm{~N} 7.53, \mathrm{H} \mathrm{4.34,} \mathrm{Cu}$ 17.10; found C 32.44, N 7.59, H 4.17, Cu 17.60.

For the synthesis of $\left[\mathrm{Zn}\left(\mathrm{H}_{2} \mathrm{O}\right)_{4} \mathrm{CuEDTA}\right] \cdot 2 \mathrm{H}_{2} \mathrm{O}, 0.35 \mathrm{~g}$ of $\mathrm{ZnCO}_{3}$ was added to an aqueous solution of $1.05 \mathrm{~g}$ of $\left[\mathrm{CuH}_{2} \mathrm{EDTA}\right] \cdot \mathrm{H}_{2} \mathrm{O}$. After half an hour of heating at $50{ }^{\circ} \mathrm{C}$
Table 4. Crystal data and details of the structure refinement of $\left[\mathrm{Zn}\left(\mathrm{H}_{2} \mathrm{O}\right)_{4} \mathrm{CuEDTA}\right] \cdot 2 \mathrm{H}_{2} \mathrm{O}$.

\begin{tabular}{|c|c|}
\hline Empirical formula & $\mathrm{C}_{10} \mathrm{H}_{24} \mathrm{~N}_{2} \mathrm{O}_{14} \mathrm{CuZn}$ \\
\hline Formula weight, $\mathrm{g} \mathrm{mol}^{-1}$ & 525.22 \\
\hline Temperature, $\mathrm{K}$ & $293(2)$ \\
\hline Crystal size, $\mathrm{mm}^{3}$ & $0.25 \times 0.20 \times 0.04$ \\
\hline Crystal system & orthorhombic \\
\hline Space group & $\operatorname{Pna2}_{1}$ (no. 33) \\
\hline$a, \AA$ & $14.5846(4)$ \\
\hline$b, \AA$ & $9.8421(3)$ \\
\hline$c, \AA$ & $13.0114(3)$ \\
\hline$V, \AA^{3}$ & $1867.70(9)$ \\
\hline$D_{c}, \mathrm{~g} \mathrm{~cm}^{-3}$ & 1.868 \\
\hline$Z$ & 4 \\
\hline$F(000), \mathrm{e}$ & 1076 \\
\hline$\theta$ range for data collection, deg & $3.2-27.5$ \\
\hline Index ranges & $\begin{array}{l}-18 \leq h \leq 17 \\
-12 \leq k \leq 12 \\
-16 \leq l \leq 16\end{array}$ \\
\hline Reflections collected & $1132 \overline{7}$ \\
\hline Independent reflections & $4201\left(R_{\mathrm{int}}=0.040\right)$ \\
\hline Data/restraints/parameters & $4201 / 2 / 254$ \\
\hline Goodness-of-fit on $F^{2}$ & 1.091 \\
\hline Final $R 1 / w R 2$ indices $[I \geq 2 \sigma(I)]$ & $0.034 / 0.086$ \\
\hline Final $R 1 / w R 2$ indices (all data) & $0.040 / 0.090$ \\
\hline Largest diff. peak/hole, e $\AA^{-3}$ & $0.65 /-0.52$ \\
\hline
\end{tabular}

the solution was cooled. Blue crystals were precipitated by the addition of $35 \mathrm{~mL}$ of cold methanol, were washed with methanol and dried at r.t. Yield: $17 \%(0.25 \mathrm{~g})$. Analysis for [Zn $\left.\left(\mathrm{H}_{2} \mathrm{O}\right)_{4} \mathrm{CuEDTA}\right] \cdot 2 \mathrm{H}_{2} \mathrm{O}\left(\mathrm{C}_{10} \mathrm{H}_{24} \mathrm{~N}_{2} \mathrm{O}_{14} \mathrm{CuZn}\right)$ : calcd. C 22.86, N 5.33, H 4.57, Cu 12.10, Zn 12.45; found C 23.19, N 5.39, H 4.07, Cu 11.83, Zn 11.95.

\section{Crystal structure determination}

X-Ray diffraction data collection for $\left[\mathrm{Zn}\left(\mathrm{H}_{2} \mathrm{O}\right)_{4}\right.$ CuEDTA] $\cdot 2 \mathrm{H}_{2} \mathrm{O}$ was performed on an Enraf-Nonius Kappa-CCD diffractometer, using graphite-monochromated $\operatorname{Mo} K_{\alpha}$ radiation $(\lambda=0.71073 \AA)$. The final unit cell parameters were based on all reflections. Data collections were made using the program COLLECT [24]. Integration and scaling of the reflections were performed with the HKL DENZO, SCALEPACK system of programs [25]. Multi-scan absorption corrections were applied [26]. The structure was solved by Direct Methods with SHELXS-97 [27]. The model was refined by full-matrix least-squares on $F^{2}$ with SHELXL-97 [28]. All the hydrogen atoms were stereochemically positioned and refined with the riding model [28]. Crystal data, collection procedures and refinement results are summarized in Table 4. The programs SHELXL-97 [28] and ORTEP-III [18] were used within the WINGX suite of crystallographic programs [29] to prepare materials for publication.

CCDC 702866 contains the supplementary crystallographic data for this paper. These data can be obtained free 
of charge from the Cambridge Crystollographic Data Centre via www.ccdc.cam.ac.uk/data-request/cif.

\section{Spectroscopic measurements}

FTIR spectra, in the range between 4000 and $200 \mathrm{~cm}^{-1}$, were recorded on a BOMEM M 102 spectrophotometer using the $\mathrm{KBr}$ pellet technique. Electronic spectra of the complexes were registered on a Milton Roy Spectronic 3000 spectrophotometer, using Nujol suspensions and aqueous solutions.

EPR measurements were carried out on polycrystalline samples using an X-band Varian E109 spectrometer and standard rectangular cavities with $100 \mathrm{kHz}$ field modulation. The measurements were performed at $4.3 \mathrm{~K}$ using an Oxford EPR cryostat and a $\mathrm{Cr}(\mathrm{III})(g=1.9797)$ sample for field calibration.

Absorption atomic measurements were performed with a Perkin Elmer 5000 equipment with a hollow-cathode lamp, single-element, Photron, $\mathrm{Cu}(324.8 \mathrm{~nm}) \mathrm{Zn}(213.9 \mathrm{~nm})$.

Ion exchange experiments

Cationic resins DOWEX50W (A) and MERCK Ion exchanger IV, 4835 (B) were used. The physical properties and specification reported by the manufacturers were for A: sulfonic acid as functional group, capacity $0.6 \mathrm{mmol} \mathrm{mL}^{-1}$, and for $\mathrm{B}$ : acetic acid as functional group, capacity $3.2 \mathrm{mmol}$ $\mathrm{mL}^{-1}$.

The resins were swollen with $\mathrm{HCl}(6 \mathrm{M})$ and washed with distilled water several times. $70 \mathrm{mg}(0.13 \mathrm{mmol})$ of [ $\mathrm{Zn}$ $\left.\left(\mathrm{H}_{2} \mathrm{O}\right)_{4} \mathrm{CuEDTA}\right] \cdot 2 \mathrm{H}_{2} \mathrm{O}$ was dissolved in $50.0 \mathrm{~mL}$ of $0.1 \mathrm{M}$ $\mathrm{HCl} .1 \mathrm{~mL}$ of this solution was inoculated in the resins and eluted with water up to $50.0 \mathrm{~mL}$. After that the resins were regenerated with $6 \mathrm{M} \mathrm{HCl}$ for resin A and with $0.1 \mathrm{M} \mathrm{HCl}$ for resin B. Copper and zinc concentrations in the original solutions and in the eluates were determined by atomic absorption. The experiments were also repeated, dissolving the complex in water instead of $0.1 \mathrm{M} \mathrm{HCl}$. The same measurements were performed with $\left[\mathrm{CuH}_{2} \mathrm{EDTA}\right] \cdot \mathrm{H}_{2} \mathrm{O}$ using resin B only.

\section{Acknowledgements}

The authors thank Mariela Pistón and Melina Mondelli for generous help during atomic absorption measurements. This work was carried out with the financial support of PEDECIBA-Química (Uruguay). E. J. B. is a member of the Research Career from CONICET (Argentina).
[1] R. C. Rowe, P. J. Sheskey, S. C. Owen, Handbook of Pharmaceutical Excipients, (5 ${ }^{\text {th }}$ Ed.), PhP \& AphA, London 2006.

[2] A. H. Lieberman, M. M. Rieger, G. S. Banker, Pharmaceutical Dosage Forms: Dispersed Systems, Vol. 1, Marcel Dekker, New York 1996.

[3] D. M. Taylor, D. R. Williams, Trace Element Medicine and Chelation Therapy, The Royal Society of Chemistry, Cambridge 1995.

[4] O. Anderson, Mini-Rev. Med. Chem. 2004, 4, 11.

[5] E. J. Baran, Química Bioinorgánica, McGraw-Hill Interamericana de España S. A., Madrid 1995.

[6] M. H. Torre, I. Viera, G. Facchin, E. Kremer, E. J. Baran, T. Porochin, V. DiDonato, C. Irigoyen, J. Irigoyen, S. Saldanha, J. Bussi, M. Ohanian, J. Fuentes, Livest. Prod. Sci. 2005, 95, 49.

[7] E. J. Baran, C. C. Wagner, M. H. Torre, J. Braz. Chem. Soc. 2002, 13, 576

[8] R. F. Hurrell, Nutrit. Rev. 1997, 55, 210.

[9] X. Solans, M. Font-Alba, J. García-Oricain, Acta Crystallogr. 1984, C40, 635.

[10] X. Solans, M. Font-Alba, J. Olivia, J. Herrera, Acta Crystallogr. 1983, C39, 435.

[11] V. M. Agre, T. F. Sisoeva, V. K. Trunov, A. Ya. Fridman, N. N. Barkhanova, J. Struct. Chem. 1981, 22, 114.

[12] M. Insausti, J. L. Pizarro, L. Lezama, R. Cories, E. H. Bocanegra, M. I. Amortua, T. Rojo, Chem. Mater. 1994, 6,707 .
[13] D. Beltrán Porter, J. B. Martínez, Rev. Acad. Cienc. Exact., Fís., Quím., Nat. Zaragoza 1976, 31, 229.

[14] M. V. Leont'eva, A. Ya. Fridman, N. M. Dyatlova, V. M. Agre, T. F. Sysceva, Russ. J. Inorg. Chem. 1987, 32, 2494.

[15] E. Kremer, G. Facchin, E. Estévez, P. Alborés, E. J. Baran, J. Ellena, M. H. Torre, J. Inorg. Biochem. 2006, 100, 1167.

[16] C. C. Wagner, S. Calvo, M. H. Torre, E. J. Baran, J. Raman Spectr. 2007, 38, 373.

[17] C. C. Wagner, M. H. Torre, E. J. Baran, Lat. Am. J. Pharm. 2008, 27, 197.

[18] C. K. Johnson, M. N. Burnett, ORTEP-III, Rep. ORNL6895, Oak Ridge National Laboratory, Oak Ridge, TN (USA) 1996. Windows version: L.J. Farrugia, University of Glasgow, Glasgow, Scotland (U.K.) 1999. See also: L. J. Farrugia, J. Appl. Crystallogr. 1997, 30,565 .

[19] F. S. Stephens, J. Chem. Soc. A. 1969, 1723.

[20] A. B. P. Lever, Inorganic Electronic Spectroscopy, $\left(2^{\text {nd }}\right.$ Ed.), Elsevier, Amsterdam 1984.

[21] B. J. Hathaway, M. J. Bew, D. E. Billing, R. J. Dudley, P. Nicholls, J. Chem. Soc. A 1969, 2312.

[22] S. Stoll, A. Schweiger, J. Magn. Reson. 2006, 178, 42.

[23] V. P. Pfeiffer, E. Schmitz, Z. Anorg. Allg. Chem. 1949, 258, 247.

[24] Collect, Nonius Kappa-CCD Software, Nonius BV, Delft (The Netherlands) 1997. 
[25] HKL Denzo, Scalepack: Z. Otwinowski, W. Minor, Methods in Enzymology, Vol. 276, Macromolecular Crystallography, Part A (Eds.: C. W. Carter Jr, R. M. Sweet), Academic Press, New York, 1997, pp. 307.

[26] R. H. Blessing, Acta Crystallogr. 1995, A51, 33.

[27] G. M. Sheldrick, SHELXs-97, Program for Crystal Structure Solution, University of Göttingen, Göttingen (Germany) 1997.
[28] G. M. Sheldrick, ShelXl-97, Program for Crystal Structure Refinement, University of Göttingen, Göttingen (Germany) 1997.

[29] L. J. Farrugia, WinGX, A. MS-Windows System of Programs for Solving, Refining and Analyzing Single Crystal X-Ray Diffraction Data for Small Molecules, University of Glasgow, Glasgow, Scotland (U.K.) 2005. See also: L. J. Farrugia, J. Appl. Crystallogr. 1999, 32, 837. 